\title{
Teaching and Doing Strategy as an Intentional Strategic Innovation Mindset
}

\author{
C. Clifton Eason \\ Samford University \\ Matthew J. Mazzei \\ Samford University \\ Robert W. Service \\ Samford University
}

There are many important keys in learning, teaching, and doing strategy today. We propose rethinking the learning strategies employed at the MBA level to make the degree more relevant. Recent calls from academia and practice indicate the need to stress adaptability using soft knowledge and skills to make MBA courses more aligned with the realities of strategic decision-making in today's business environments. We emphasize that while traditional strategic framework models and diagrams have their place, today's professionals must be prepared to make decisions in unstructured and highly ambiguous situations that traditional models do not address.

Keywords: Teaching, Strategy, Learning, Innovation

\section{INTRODUCTION: THE PROBLEM IS OUR OPPORTUNITY}

Why do we observe with individual and organizational actions such wide strata of behaviors, models and performance? A typical undergraduate or graduate-level strategic management course should help answer this question. Topics covered in any number of popular textbooks give guidelines for testing and modeling, but do not require unstructured deep innovative new thought. These text authors present theories, frameworks, and research that has shaped the field over the last fifty years. Many include examples of strategy being executed in organizations across the world - either in short anecdotes or extensive case studies. These can help demonstrate and reinforce the knowledge and understanding developed over these decades. However, there are dangers in "stories" as guidelines to developing or teaching strategy. Success in practice requires moving beyond the ability to follow models about strategy toward mindsets that provide deeper understandings of the implications of complex interactions of environments, constituents, context, and processes involved in strategic learning and practice. It is time to change how we teach strategy (Bell, Filatotchev, Kruse, \& Hitt, 2018).

While scholarship continues to advance with fierce competitiveness, there continues to be a lack of connection between scholarship, pedagogy, and practice (Bell et al., 2018; Mintzberg, 1994, 2004, 2009; Powell, 2017; Priem, 2018). Likewise, current academic reward systems do not move researchers to 
engage in trend-setting innovative, usefully applicable research - instead, keeping us in the known narrow focus of problems, opportunities, and threats. This approach is an impediment to broader success. Practitioners essentially never turn to academic journals for insights for improving their personal skills or operational practices (Shapiro \& Kirkman, 2018). Systematic excellence in strategically addressing critical issues in academic research must be rewarded if we are to shift academia toward leading versus following in the development of solutions (Service \& Loudon, 2015). At the foundation of strategy, relational and innovative mindsets rule in practice and theory. Our mindsets, known or unknown, surround every decision we take - either facilitating or impeding developmental actions.

We do not intend to downplay the countless contributions made to the field of strategic management. Yet there remain questions about how effective scholars are in considering new ideas, models, and theories for strategy. Making things useful for a critical mass of practitioners must move to the top of the list in importance: relevance ultimately matters. Proclamations of many authors show clearly that most characteristics and models of conventional thinking in the strategic management field are outdated and often harmful.

Most of the theories detailed in popular textbooks were developed thirty or more years ago (Bhardwaj, Crocker, Sims, \& Wang, 2018) when the internet had not been widely adopted, phones were tethered, and an inbox was something that sat on a desk. Times have clearly changed, but how has the innovation and development in our teaching of business processes and models changed? Is strategic management pedagogy now a watered-down boiler-plate series of terms, frameworks, and checklists? Are our theories still appropriate, or are they outdated? Are the concepts we deliver to students, through everincreasing costs of higher education, fulfilling a need to develop better organizational managers and strategists? Can we expect the innovation necessary to make economic-expanding progress from following the current strategic models and methods? We think not.

Looking at the lack of progress in the global political arena with debt, crime, addiction, healthcare and immigration (naming only a few), we can all acknowledge that discovery and new methods basically never come from academia's thousands of "new" articles every month. Organizational research in schools of business needs to recognize that commercial organizations are at the core of societal progress. In these areas, the current authors see answers that do not bode well for the current state of strategic learning and teaching. Real disconnects exist, and it should be academia that meets and addresses our own issues. A PayScale Inc. survey that found $50 \%$ of employers say college graduates are not ready for the workplace, "lacking in interpersonal skills, problem solving, effective writing and oral communication, and the ability to think critically and analytically" (Friedman, 2018, p. 21). Will we in the academy begin to lead, or will we continue to lag and lose all impact we could have in affecting individual, organizational, and societal progress?

When all teach the same things - theories, frameworks, case examples - from the same sources, where does the innovation and ingenuity come from? If professors cannot innovate teaching of strategy, how can we expect our learners to innovate? Only innovation provides economy expanding, improving futures (Olsen, 2012). If the generations of new strategic leaders all have the same backgrounds and exposures to scripted thoughts, how do firms develop creative new business solutions to long-standing and emerging problems? Note many of the founders and CEOs of the largest organizations in the world are not MBAs (Jeff Bezos, Bill Gates, Reed Hastings, Larry Page, Mark Zuckerburg, to name a few). This manuscript's purpose is to encourage academics to think broadly while adapting and adjusting rapidly as we strategically innovate the future in the murky present under a perplexing past.

\section{An Answer and Why It Is a Necessity}

Reality requires decisive, adaptive application to meet the need to challenge people to think more intensely at each subsequently higher level of education. Yet, "Recent college graduates are struggling with autonomy and have more trouble making decisions (Alsop, 2008, p. 115)." Learning must include a

level of struggling to figure out how to approach challenges and develop new keys to success. Bogers, Chesbrough, and Moedas (2018) encourage us to move "toward embracing uncertainty and openness" (p. 
10). If we continue to generate university graduates that cannot decide or figure out problems on their own, the academy is doomed.

Considering the calls within and outside of the academy, it is past time we address how we are developing future strategic leaders (Powell, 2017). This manuscript contributes to the field of strategic management by practically and pedagogically challenging strategy-making and the way it is taught. Under recognition of the monumental contributions of past work in this field, we attempt to build upon the traditions of generating new innovative ideas - thus pushing new frames of strategic thought. We propose ways to rectify errors not by revisiting causes but by proposing new solutions. As Churchill said, if we open an argument between the past and the present, we will lose the future (House, n.d.). Business education is at a crossroads. We can continue teaching innovation and strategy with formulaic methods, frameworks, and processes; or we can be innovative and explore and test new ideas that perpetually push students and teachers. Innovation must move into the academy and produce changes if universities are to remain relevant in developing leaders that create a future that young, upwardly-striving professionals desire (Fischer, Dietz, \& Antonakis, 2017). In our instant global information world of fast-paced innovation, we must think more innovatively and strategically to generate competitive advantage.

Traditional strategy models when applied inflexibly, inhibit broader, more comprehensive thinking. It is important that both learners and doers understand the limits of these tools before using them in an increasingly ambiguous marketplace. In the "real world," developing a strategic plan with simple fill-inthe-blank models and step-by-step implementation guides will produce a strategy that is stale by the time is has been completed... and that matches the strategy of everyone else using the same models. We must shift from teaching how it has been to how it is becoming.

\section{STRATEGIC MANAGEMENT - BACKGROUND}

The field of strategy developed from literature on business policy beginning with Porter's significant contributions in the late 1970s and 1980s. His valuable work looked at the forces shaping competitive dynamics and strategy. The importance of consistency, value chains, competitive forces, differentiation, sustainability, the "why" behind strategy, systems of activities, and more found in Porter's (1980, 1985, 1990) work must not be overlooked. Porter shaped the field in dramatic ways, serving as a foundation for how we continue to view strategy.

Jay Barney and others delved into Porter's work and added greater detail in how firms reinforced strategic positioning and created sustainable competitive advantage. Through a bundling of resources and capabilities in complex and socially ambiguous ways, organizations could create value that withstands threats. Through applying Barney's VRIN model's characteristics of value, rareness, imperfect imitability, and non-substitutability, businesses created value through unique offerings to customers (Barney, 1991). Evolution of this resource-based view (RBV) of the firm included recognition of the value of dynamic capabilities and of focus on knowledge as key resources for achieving organizational success. Dynamic capabilities represent processes that allow firms to integrate, reconfigure, gain, and release resources as a means to develop advantages (Teece \& Pisano, 1994). Knowledge-based theory of the firm (Grant, 1996) adapts RBV toward integration of new knowledge with tacit knowledge as a true source of value for success.

Porter's and Barney's works and complementary contributions that followed have stood the test of time, but chinks in their armor are appearing. Successful firms today are seeking growth, diversification, and profitability in ways that challenge traditional thought. For instance, why would a company like Apple with its highly popular and profitable personal electronic device lineup move aggressively into the traditional, slow-growth world of automobiles? Why would Google - an advertising firm - seek opportunities in space exploration? Should not traditional barriers of entry and expected retaliation of incumbents keep out these new, inexperienced entrants?

Porter's model was suitable for a manufacturing economy, and Barney's work was well equipped to describe strategy making in a service-based economy, yet, neither, by themselves or in combination, are descriptive enough to help understand and guide decision-making today. Only in regulated industries or 
the most traditional of firms (and academia accreditation) do we see the old "strategic" plan book. As information security/technology rapidly advances, it often seems that Amazon and Walmart could be the only retailers still standing when the digital dust settles to a more steady state from the big-bang of the internet revolution. With emphasis on organizational learning and continuous improvement, dynamic capabilities and KBV were movements in the right direction for understanding these advances. Yet even those perspectives were not supported by the digitization of business models. AI, ES, ERP, MISs of all types, learning systems, visual analytics, dynamic modeling, and more move us to new levels with algorithmic precision and speed. Now, with complete metamorphoses and business model reconstruction built around digitization, increasing levels of data, and technological advances in capacities and analytical processing power, we see the necessity of a more complete transformation in the strategic decisionmaking process: teaching, learning, and doing must reflect this.

\section{TEACHING AND DOING STRATEGY: NON-TRADITIONAL APPROACH REVIEW}

We suggest that an appropriate approach is to begin with recognizing that "events are the result of multiple factors coming together and interacting in complex and often unanticipated ways..." and we should "Obtain multiple perspectives" (Corbin \& Strauss, 2008, p. 8)." Then use thought experiments (Isaacson, 2007) to visualize the basics of improvements. Think about what you can be, who you must deal with, and the situations within which improvement must occur because understanding context and process can sometimes be more important than the content we teach. It is about seeking to discern where you are and where you need to be - and then "minding the gaps."

Mintzberg's (1994) The Rise and Fall of Strategic Planning recommends a "mindset approach" to strategy making. He argues that the process by which strategies are actually created should be more about informal learning and personal vision than formal planning. Mintzberg stresses that over-planning can narrow a company's vision, breed a political atmosphere, and discourage change. Repeatedly, Mintzberg underscores that the discontinuities that we see cannot be planned for. Thinking otherwise encourages a fallacy that we can predict the unpredictable. Some of his most useful recommendations - ones that have served us well in our careers in and outside academia - can be found in the following words: "Anecdotal evidence is supposed to be soft, biased, and superficial. Yet we have just seen exactly the same about hard data (p. 97)... the term "strategic planning" has proven to be an oxymoron" (p. 321). We all too often see data and associated analytics used to build or support a predefined story instead of discovering facts. We see the world we want to see, and we seek confirmatory evidence under normal human attribution errors with unintended consequences abounding because of the narrowness of human insights (Dobelli, 2013). Instead of only teaching how to address problems we routinely see, we should teach students to be ready for the new and the different (Heames \& Service, 2004; Priem, 2018).

Strategic solutions too often stress politics and divisiveness on expedient issues rather than the core problem or issue (Blair, 2010; Bush, 2010; Obama, 2004, 2006). Start strategic thinking with realism and honesty, identifying the underlying core issues in order to develop solid frameworks that improve chances for intended changes and lasting solutions (Peters, 1987, 2003). Assuring the sustainability of organizations and institutions requires identifying core issues, restating complaints as suggestions, and eliminating excuses for inaction (Dobelli, 2013). Action remains key; for when you do nothing, you have nothing to evaluate and adjust (Duckworth, 2016). Approaching anything in a strategic manner requires that the questions be the right ones addressed with truth and gusto (Rumsfeld, 2013). We should direct our energy and effort toward doing, learning, and teaching how to shift to a continuous innovation mindset guided by clear thinking for a more desirable future.

When leaders are not afraid to make decisions to pursue new directions, the strategy emerges as a deliberate strategy. The process is "constantly evolving... [for] strategy is not a discrete analytical event... Rather, it is a continuous, diverse, and unruly process" (p. 46). After all, "93 percent of all companies that ultimately become successful had to abandon their original strategy" (Christensen, Allworth, \& Dillon, 2012, p. 87). 
Those outside of academia have learned much from research represented in Levitt and Dubner's popular works of the last few years. Their Think like a Freak (2014) extends thinking about the usefulness of economics for a large audience who does strategy by pointing descriptive, prescriptive, instructional, and predictive data toward innovative usefulness. The authors note that "it's easy to let your biasespolitical, intellectual, or otherwise - color your view of the world... When was the last time you sat for an hour of pure, unadulterated thinking?" (p. 10). Indeed, how often do we think about entirely new, innovative approaches rather than repurposing old ones? Strategies "are multidimensional cause-andeffect questions... their outcomes are both distant and nuanced. With complex issues, it can be ridiculously hard to pin a particular cause on a given effect" (p. 23). These authors' work can be a guide to developing more innovative strategic thought mindsets: Think like a curious kid noticing new facts and views with few assumptions and expectations and little overthinking - open to the obvious, the totally unexpected, and everything in-between.

Dobelli's (2013) The Art of Thinking Clearly describes common cognitive biases. Cognitive biases are our thinking predispositions that are used to form opinions, guide decisions, lead us to buy a product, select a spouse or friend, pursue a particular strategy, etc. These common biases influence our considerations of arguments, form our frames of reference and mental models, guide our views of others, direct our judgments and actions, and, thus, help us determine and justify our place in the world. Cognitive biases most often keep us in our known and unknown ignorance (i.e., unawareness). These mental favoritisms or misguided interpretations can keep us from being innovative in products, organizations, selves, or approaches. "To believe that we can completely control our emotions through thinking is illusory... Thinking is in itself not pure, but prone to error" (p. 301).

Since news as hyped headlines is the norm, all strategists need to figure out why there is so much dichotomous thinking about successes, failures, and causes. The media's use of the marketing concepts of framing and messaging requires that strategists view all "news" carefully. The Righteous Mind: Why Good People Are Divided by Politics and Religion helps in understanding where others are coming from with their pronouncements about the results of strategies (Haidt, 2012). From Haidt, one can deduce the following principles that all need to understand in order to become more effective innovative strategist: 1) reciprocity, 2) thought experiments, 3) thinking to learn, 4) conformational biases, 5) "Intuitions come first and strategic reasoning second" (p. 82), 6) innate understanding forms the first draft of our life's beliefs and actions, 7) shared intentionality, 8) morality binds but blinds, 9) evolution can be fast as genes and cultures coevolve, 10) innate does not mean unmalleable - it means organized in advance of experience, 11) pronouncements in books, analogies, research (empirical or not), and all narratives are not necessarily true or false - they just are - it is relevance that makes them useful, and 12) "Markets Are Miraculous" (p. 106). We believe understanding these are important in our teaching, learning, and strategizing.

Isaacson (2014) presents questions and answers that provide guidance in developing more useful and innovative strategies. "What is imagination? . . It brings together things, facts, ideas, conceptions in new, original, endless, ever-varying combinations (p. 18)... Innovation requires articulation [as does strategy] (p. 90)... people take insights from multiple sources and put them together... All ideas are born this way" (p. 68). Given these comments, strategists must improve social skills toward understanding what motivates people in all capacities - as buyers, owners, workers, strategists, politicians, and so on. The reasons for "doing" are key to developing and sustaining strategic advantage. "The true test of leadership and management is whether or not the leader or manager has helped those they influence become the best they are capable of becoming" (Service, Reburn, \& Windham, 2017, p. 68). Yes, understanding others' strategic reality must be grounded in bounded rationality and behavioral economics. Satisficing occurs over maximization because of necessity and cognitive limits. Practitioners also follow Charan's (2015) recent work for strategy and leadership-learning and practice: 
Taking control of uncertainty is the fundamental leadership challenge. You need the following five capabilities: 1. Perceptual acuity. 2. A mind-set to see opportunity in uncertainty. 3. The ability to see a new path forward and commit to it. 4. Adeptness in managing the transitions. 5. Skill in making the organization steerable and agile.

As Charan stresses, instead of fearing uncertainty, take the world's largest problems as business opportunities.

George and Sims (2007) interviewed "125 leaders to learn the secrets of their development as leaders" (p. xxvii). A key finding was that "Leading a company is like doing multiple repetitions of threehundred-pound weights. No one can lift three hundred pounds unless they start much lower and work their way up" (p.21). To get better at strategy, do strategy. "True inspirational leadership is more a matter of character than achievement" (p. 7). You get your best results from others by inspiring a fire within them - not building a fire under them. "Leadership excellence is the ultimate strategy for success" (Nielsen \& Sirkel, 2017, p. 19). Landsburg's (1993) Armchair Economist changed our minds often about leadership, giving us other views that solidify strategic points. "Most of economics can be summarized in four words: 'People respond to incentives.' . . . Our working assumption is that whatever people do, they have excellent reasons for doing. If we as economists can't see their reasons, then it is we who have a new riddle to solve" (p. 19).

Mintzberg, Ahlsrand, and Lample (2005) debunk much of what we teach about organizational strategy thus supporting our wide-ranging call for new approaches related to teaching and practicing strategy:

"The management textbooks contend that well-defined polices [strategies] are the sine qua non of a well-managed company. My research does not bear out this contention" (p. 196)... "[Most strategy managers] proceeded by trial and error, constantly revising their strategy in light of new experiences" (p. 22).

Strategizing revolves around rich and complex conversations and views that can create unexpected combinations of insights. Strategic opportunities for innovation usually do not emerge from sterile analysis and number crunching. Meanwhile, experience and attention can lead to opportunities for novel and useful insights. Mintzberg (2004) reminds us that "Easy formulas and quick fixes are the problem in management today" (p. 1). "The practice of management is characterized by its ambiguity... we need leaders with human skills, not professionals with academic credentials" (p. 18). Strategically, mangers must be effective in learning, teaching, and practicing skills of reflection, generalization, analysis, worldliness, collaboration, and proactiveness (Mintzberg, 2009).

Journalist Malcom Gladwell $(2005,2008,2013)$ translates research into somewhat counterintuitive advice or principles that are useful to practitioners. His Tipping Point, Blink, and Outliers have all been best sellers with arguments that offer practical advice to anyone who wants to strategically lead more effectively. In Outliers, Gladwell (2008) tells us with convincing data and logical arguments that "Success is the results of what sociologists like to call "accumulative advantage" (p. 30)... [which] involves someone or some group working harder than their peers" (p. 239). Consequently, employers in our global economy are demanding highly educated people who can adapt, think, and innovate (Calk \& Patrick, 2017). In teaching, a distinctive of the personal, hands-on, minds-in, relational touch demonstrates the process of instilling thinking in learning (Gladwell, 2005).

Porter, Lorsch and Norhria (2004) support these ideas of learning beyond models and theories and moving toward better understanding people and exhibiting soft skills. Their "Seven Surprises for New CEOs" article calls for CEOs to understand: 1) They cannot run the company, 2) giving orders is costly, 3 ) it is hard to know what is really going on, 4) you are always sending a message, 5) you are not the boss, 6) pleasing shareholders is the goal, and 7) you are only human. CEOs must learn to manage the context, requiring everyone to do strategy - not just managing daily operations. 
Good People: The Only Leadership Decision That Really Matters from a noted entrepreneur, strategy advisor, and author presents a Goodness Pyramid with the ideas of balanced "wholeness in wisdom and respect; compassion of generosity, empathy and openness; and the truth of integrity, self-awareness and humility" (p. 240). This practitioner favorite reminds us that it is all up to us, for everything begins and ends with respecting people and having unalterable honesty and openness values. Effective leaders influence others to accomplish to the greatest of their ability (Tjan, 2017).

Business intelligence and decisions are at the heart of executive education, and "One of the most important skills being taught... is how to best analyze data... It is a tool set that every student is going to need" ("Data-Driven," 2017, p. 17). Until more people can think and clearly define the who, what, where, when, how, and why kinds of data needed and kinds of data available, all the data in the world will not help. Strategic thinking precedes, follows, and is aligned with data collection and usage. But never forget the "why" question (Sinek, 2011).

Success calls for extended strategic mindsets: Don't just think outside the box; redefine the box. In Schawbel (2013) quotes Colin Powell as saying, "Excellence is not an exception, it is a prevailing attitude" (p. 161). The intrinsic and extrinsic value of the innovation mindset and its processes of constantly focusing attention to doing the new and the different cannot be over emphasized: Teach strategy toward this innovation mindset. Strategically investing in ideas regardless of their sources requires broadening our scopes to include big and small repurposing improvement.

Collaborative strategic leaders who exemplify innovation provide the impetus for successful change that allows individuals and organizations to become and remain relevant (Drucker, 2013). Strategic innovation is a balancing act that strategists must learn since creative success is hard to sustain over time. Innovative strategic mindsets lead to understanding the how and why of alignment of divergent and convergent thinking. Creators are often bad at evaluating the possible success of their own creations; and managers are not much better than the general public at predicting success of novel ideas (Berg, 2016). We must think and rethink with critical and creative mindsets. The literature on organizational change and leadership helps define how we might meet these mindset goals with the specific interpersonal skills of: the ability to motivate, superior communication, and team-building excellence (Gilley, McMillan, \& Gilley, 2009). Beyond these skills is grit, which is a combination of passion and perseverance exemplified by constant and relentlessly pursuing goals. Research shows endurance is rare, and giftedness is seldom enough (Duckworth, 2016).

Using academic articles and popular literature together provides better support for gaining and keeping an advantage. Sustainable advantage is possible with bold, new, innovatively strategic thinking about technology, social change, and humanism. It can work when one is attuned to recent trends. Sinek (2014) stresses "choice," saying that leadership is a choice and often a hard one. As with strategy, we see in leadership that not many really want to commit to the lifestyle and work required to lead strategically. One of Sinek's main points states that employee engagement is seen as a way to avoid being data rich and information poor. It is important to establish the proper system of rewards. Then have the right people in the right places. Link people, processes, and strategy with operations. Along this same tract, we see clearly that in today's overly informed world that the attention of top people is the most valuable resource organizations have. Engaged attention is the most valuable resource you have beyond life itself (Davenport \& Beck, 2001).

Recognizing that conflict is inevitable when everyone is involved in strategy-making can be useful when we minimize harmful effects by: creating fair policies, correct hiring, identifying the real sources of conflict, and putting into place a resolution system that fits your organization. It all starts with describing the conflict properly and having an open door policy (Blackard \& Gibson, 2002). Build a sense of shared commitment and community by letting employees engage in activities that connect people (Cohen \& Prusak, 2001).

Social capital is all of the activities that connect people; it makes an organization more than just a group of people. Simply silencing conflict can wreck a company's strategies. Good leaders recognize the power and intellect of their subordinates. They build coalitions for advantage and legitimacy as well as to garner more resources and strategic ideas (Perlow, 2003). The authors continue, noting that strategic 
leaders recognize that "[L]ikeability is truly the secret... being unlikeable is a form of social cancer" (p. 19). As Manzoni and Barsoux (2002) show, subordinates are highly sensitive to signals sent out by their bosses. So look, act, and speak with care. The majority of bosses have to work to overcome aggression, impatience, and tendencies to micromanage. Relatedly, O'Loughin (2003) states that Warren Buffet makes all decisions in the context of how the move will affect owner-partners. Buffet says instructional imperatives must be designed not to overrule rationality and destroy otherwise good managers and leaders. Professors, too, must own this imperative.

Louis Gerstner turned IBM around from the largest loss in its history. He said true leadership requires commitment, passion, and determination. He did away with the belief statement and used a number of strategic mindset principles. In particular: 1) Outstanding, dedicated people make it all happen as a team; and 2) We are sensitive to the needs of all employees and to the communities in which we operate. Gerstner said that win, execute, and team defined all he did (Gerstner, 2002).

Relatedly, from one who is considered by many to be the best CEO of the $20^{\text {th }}$ century, we hear similar charges for dealing with people. Jack Welch stressed the importance of people, originality, creativity, and common sense. As he said, speed works; for when we wait, we are usually too late (Berg, 2016; Welch, 2001). Make everything active and interactive (Klein \& Napier, 2003) because, according to Colin Powell, "[P] eople aren't just a piece of the puzzle, they are the puzzle" (Harari, 2005, p.21).

Those doing strategy well teach by example. Pulitzer Prize winner Thomas Friedman gained fame by describing coherently what has been and how that led to an open world where we compete with everyone everywhere all the time. Revisiting one of Friedman's latest works, we agree that a "better education should aspire to achieve: ingenuity, creativity, and the inspiration to bring something "extra" to whatever the student winds up doing in the world (Friedman \& Mandelbaum, 2011, p. 133)... education is the foundation of economic strength" (p. 355). It is our aim to meet this call as professors and strategists to prepare those in our charge to improve the future by recreating it. "Whatever can be done will be done. The only question is will it be done by you or to you" (Friedman, 2005).

Friedman (2005) identified ten flatteners - things that level the global playing field, and these should be taught, learned, and totally understood. They were enabled by a convergence of a more level playing field, new rules, new fields, and new players. These flatteners have fueled the need for new, strategically educated and informed leadership and stakeholders. Friedman's call for "versatilists" who can do many different things in many different cultures supports our call for education beyond rules and models.

John Allison, past chairman and CEO of BB\&T, was named one of the decade's 100 most successful CEOs in the world by Harvard Business Review in 2010. As Allison (2015) notes, "Thousands of Books have been written on strategy" and it is hard to add anything new or different (p. 117). Yet, there are still many issues in the doing and teaching of strategy, as the gaps in organizational performance strongly indicate. "[T]he fundamental role of an education system becomes self-evident: to teach students to think critically, to think logically, and thereby to reason objectively based on the facts" (p. 40). Allison's assertions point toward how we should teach strategic management and leadership.

We in academia are too often more about self-protective syllabi and checking the assurance of learning boxes than developing effective people to meet the world as it is becoming. We should take a step back and stress learning, starting with the facilitator; focus on learning over teaching. Academically refereed research publishing outlets are demanding empirical studies to the detriment of more innovative progress. The most useful of concepts are not always tested empirically. Too many studies are about too little, too late - and we admit guilt here, as well. We must move from researching, teaching, learning, and practicing how it has been to how it is becoming for "our minds insist on seeing the world as it was... Achieving greater creativity through changes in perceptions [must be the goal of teaching]" (Stern \& Deimler, 2006, p. 349).

A 2018 Wall Street Journal article found that a majority of peer-reviewed scientific journal articles cannot be replicated. When you consider that the final scientific question for proof is that there are no alternative explanations, it becomes essentially impossible to finally "prove" something scientifically. "The chief cause of irreproducibility may be that scientists, whether wittingly or not, are fishing fake 
statistical significance out of noisy data... The social psychology that informs education policy could be entirely irreproducible" (Wood \& Randall, 2018).

Looking at what we produced, studied, taught, and still read in refereed journals' empirical studies in the social sciences, we see little evidence that we have proven almost anything of use in meeting the realities of a globally evolving AI world. Moreover, the popular press is filled with many misleading "facts" and statistics. Incompleteness of reports, low levels of knowledge of the reporters, and giving people what they want to hear are key reasons. Analytics and its data tell a story, just as any opinion piece does (Blinder, 2018). When people learn to find information, analyze it, adapt and simply think, they can handle what comes their way in this evolving world. Teaching this involves balancing content, context, process, and understanding resultant outcomes.

Learning strategy today too often revolves around Nth edition textbooks with overused models and cases. Cases must be used with care and models adapted and applied with wisdom. Cases are stories of after-the-fact situations, and they can lead students to think that they can handle the new and the different simply because they have handled a contrived story. Selective inclusion and exclusion distorts the muddiness of reality. In actual commerce, nothing is quite so easy as "find this, solve that, and you'll get 'the' answer." Cases and models can be good as tools, but they do not mimic the complexity of the real world. Nonetheless, utilizing current examples, trends, and cases on decision-making, exercises, and experiential learning opportunities when they require students to stretch can help develop and deliver traits that job-providers value: curiosity, responsibility, accountability, reliability, confidence, decisionmaking abilities, critical/creative thinking skills, people/soft skills (Bedwell, Fiore, \& Salas, 2014; Calero, Barreyro, \& Injoque-Ricle, 2018).

In his book on leadership, myths and realities, retired U.S. General Stanley McChrystal says of his experiences: "As we deconstructed events, we discovered that even where my recollections were accurate, they were stunningly incomplete accounts of history (McChrystal, Eggers, \& Mangone, 2018, p. xii)." As you review any news or other form of media account of past events, be it a case study or any "factual" account, remember that anything a human produces is a perception. Perceptions almost never are complete or totally factual.

\section{Connecting Practice and Pedagogy}

Presenting expanded concepts about teaching strategy requires switching from doing strategy to thinking strategically as well as jumping between teaching and learning. In part, the format and methods used here mimic today's vastly changing dynamic vocations, education, and competitive advantages. Teach toward messy and quick versus the silver platter of college syllabi.

The traditional paint-by-numbers approaches to teaching strategy will not create the needed future. The stylistic approach we use here is purposeful in part to demonstrate how to better engage students in their own learning by presenting issues of interest to them in a form that will often challenge common notions of strategic wisdom. Challenging students necessitates thought, and only active mental engagement leads to self-improvement and learning (Molenberghs, Prochilo \& Steffens, 2015).

Powell (2017) states that strategy should be demonstrated by activities and permeate all aspect of an organization as states of mind. Further, he demonstrated that realized strategy is less about a path than choices of paths; available through seeking and developed using all manner of inputs, methods, and analyses toward a multiplicative balanced way of teaching, learning, and doing. "[A]nalyzing industries, choosing the scale and scope of the firm, positioning for competitive advantage, and seeking differentiated resources and capabilities - have outlived their usefulness" [bolding ours] (p. 163). "[Strategy] is not a checklist of factors, or a boxes-and-arrows system" (p. 181).

Building on Powell, the Academy of Management Learning \& Education special edition is dedicated specifically to: "revisit what we teach in strategic management courses and how we transfer theoretical and empirical knowledge (p. 5)... [to] expand-its relevance and value creation (p. 6)... [to address] the increasingly frequent calls for more relevant and practically applicable strategic education (p. 3)... [for] what we teach is actually bad for practice" (Bell et al., 2018, p. 3). The key points from this excellent publication can be represented through the following excerpts: "Strategy professors must continually 
update their content expertise and pedagogical skills. . [S]trategy teachers cannot rest on old frameworks from the 1980s and $90 \mathrm{~s}$. . . given the rapid changes we see in the business world (p. 4). . . Teaching strategic management well involves instilling in students a life-long process of improving critical thinking ... concerning strategic issues" (Priem, 2018, p. 1). It is appropriate that approaches mirror much of Priem's prescripts in teaching MBA level and professional development strategy but not totally in undergraduate teaching.

Bhardwaj et al. (2018) discuss "research that has identified a gap between what is often taught in business schools versus what organizations and societies need... students continued to fall short on problem solving skills and were especially at a loss with unstructured problem solving, which is common in strategic situations" (p. 8)... "problem solving and decision making... Neither is taught with the rigor of conventional strategy topics" (p. 12). These authors go on to say that none of the leading textbooks they sampled adequately covered what is needed in the presence of ambiguity, uncertainty, and incomplete information that one actually sees in real strategy making. "The fundamental shifts taking place in society, business, and technology mean that the challenges of solving complex, ambiguous, consequential problems will only rise in the years ahead" (p. 46). The truism that "Almost any fitness program will get results if a person actually does the work, and no fitness program will get results if they do not" (p. 166) applies exponentially to teaching, learning, and doing strategy.

\section{NEW DIRECTION STRATEGY COURSE: DOING AND LEARNING - CONTENT THAT WORKS}

One way to introduce MBA students to incorporate skills of problem identification and solution generation is to have a capstone course centered on a student-selected individualized what and why. Taking into account course objectives and assigned readings, students should reflect on what they would like to explore and strategize how to accomplish this in an area of their choosing. In parallel, they should answer the important question of why it is of interest and importance. These central questions - and one's own personal growth in research, writing, project deliverables, and learning — should lead learners toward becoming more strategically effective with their own what and why even as they change through life. Yes, learners are tailoring the course to their own wants and needs. As a facilitator, the instructor can share as an example what he/she would you like to explore more. For us, our "what" in this manuscript is to redesign the MBA strategy capstone course. Our "why" is: to better address the new realities of global competition though teaching and doing strategy differently. All assignments need to revolve around student-identified issues.

We are suggesting something akin to what many European universities use to guide individual advanced study: the Oxford Tutorial method. In this method, a student approaches a professor in a given discipline, and the professor questions the student about what they would be interested in pursuing. Then the professor instructs the student to read suggested material that is directed toward a student paper on something in the student's stated area of interest. The student then sets up an appointment to bring in their results in order that the professor can assess the student's work toward making further assignments. This process continues until learning has occurred and been demonstrated.

Focus attention on building an interactively engaging learning community around students and professors jointly acting as facilitators, sharing experiences and thoughts about students' whats and whys. A feedback-rich classroom should mirror a well-run corporate meeting demonstrating managing, leading, strategizing, professionalism, contributing, and giving and receiving feedback. 'Figuring it out' is a key success factor (KSF), that teachers should demand from learners. In the traditional model the teacher gives lessons on which you are subsequently tested. Our model attempts to mimic life where learners are exposed and tested as they have to figure out the lessons they learned and how they can use them going forward. Application of learning makes it stick. 


\section{Course Intent and Teaching Principles}

Make courses fun and informative, adding value to teachers and learners through a lively, feedbackrich environment. Learners should strategically discuss and debate issues of importance to them, their organizations, and other external environments. No issue is too big or small. A key to life in today's abundance of attractive distractions is learning to be fully present and engaged. Discuss or decide by default by not discussing.

\section{THE "DISTINCTIVE" AND "INNOVATION" IMPERATIVES - TEACHING, LEARNING, AND DOING}

Success points toward two organizational and personal imperatives. The first necessity is a clear understanding why someone would do business with your or your organization - a distinctive competitive advantage. The second essential is becoming and remaining innovative. Management guru Peter F. Drucker (2013) rightly proclaimed: "Most innovations... result from a conscious, purposeful search for innovation opportunities" (p. 144)... If diligence, persistence, and commitment are lacking, talent, ingenuity, and knowledge are of no avail" (p. 156). The cost of an innovation must be compared to the ultimate cost of not innovating (Buford, 2014).

\section{Irrefutable Laws for a Strategic Life}

Findings in psychology, science, theology, business, academia and more, have led to development of guiding principles for remaining strategically innovative:

1. Be certain you might be wrong; but start with an answer.

2. We learn much from questions allowed to stay with us.

3. The answers to all larger questions are more questions.

4. Don't stay wrong long. You always start from where you are, so be sure where that is!

5. Correct best answers will not stay best nor correct long. Failing to fail is the worst of failures.

6. Seeing beyond the obvious requires more than the eyes.

7. The insights of the stilled mind serve all well.

8. The process of forming mental pictures of the future enacts what is envisioned.

9. Realize and use the capabilities of yourself and others: character makes or breaks.

10. Have a strategy for all 'important' things and assume it is important; it may be in the end.

Character, like leadership and management, is built, not given (Miller, 2018). "True inspirational leadership is more a matter of character than achievement" (Nielsen \& Sirkel, 2017, p. 7).

We are in a perfect storm of disconcerting academic and societal issues combined with "global weirding" of vocations enabled by rapid changes with artificial intelligence. These advancements show no sign of slowing. Use of "Cobots" (robots that collaborate) in innovative endeavors is here (Steinberg, 2017). These shifts are more and more progressive. We are on the brink of linking human thinking with the look-up power of all search engines combined. This might indeed make obsolete traditional intellect and education (Service \& Reburn, 2016). The science fiction of our youth is rapidly becoming reality, extending firm capabilities.

Watch trends such as these, and teach and practice the soft skills in the classroom, putting learners in uncomfortable positions. This emphasizes real-world adaptive skills rather than mere memorization and selection. Today's students can calculate, define, recognize and select, but seldom can they apply the content that they had been tested on. Move toward:

1. Providing broad, overriding course objectives: IDing how objectives are meet in assignments.

2. Fitting content to the students. Use their examples to clarify concepts, etc.

3. Addressing student opportunities and threats using their solutions.

4. Building relationships: cyber + in-person. All are evaluating everyone all the time.

5. Teaching and learning through unorthodox differentiation: in classes, demonstrate adaptability. 
6. Using tasks instead of tests. Eliminate selection exams, and require critical thinking and application.

7. Using technology only to add value.

8. Practicing development of one's own thoughts and expressing them in a group environment.

9. Demonstrating understanding of the imperatives of distinctive competencies and innovation.

10. Establishing a feedback rich environment in classes, patterned after corporate department meetings.

Demonstrate strategic rapid incremental innovation within all teaching, learning and doing. In capstone experiences, convey insights that help to see our worlds in deeper ways with a professional mentality.

\section{Teaching as the World is Becoming versus as It Has Been: More Effective Strategy}

Grant and Baden-Fuller (2018) note that educating for judgment and wisdom, requires expanded "cognitive skills... [of] judgement in prioritizing issues, choosing among analytical tools, and interpreting predictions; insight into complex causal interactions, and intuition in recognizing patterns and anticipating changes" (p. 11)... "[I]t is uncertainty and contextual idiosyncrasies of strategic situations that rules out mechanistic analysis" (p. 21). Regarding simulations, these authors rightly proclaim "There is always a danger that the challenge becomes one working out the algorithms of the program rather than addressing realistic... business situation" (p. 26). Therefore, only by "teaching both the theory and the practice do students learn to appreciate the power and limits of the field's knowledge" (p. 31). We must admit that "Learning a fixed set of facts during your schooling is not going to provide very well for your whole life, since the world keeps changes" (Felsenthal \& Pine, 2018, p. 84-85).

A lag exists between research and teaching as well as between realities and teaching. Too little effort to establish appropriate contexts exists in strategic considerations. And "Emotions and quests for legitimacy are a part and parcel of such newer strategic thinking" (Peng et al., 2018, p. 12). Emotions matter, and "[we need] to discover systematic differences and similarities in firms across a wide variety of context" (Buckley, 2018, p. 2). It is appropriate to use theories and their resulting models and guides, but only if those paradigms act as general guides.

Moschieri and Santalo (2018) find that professors who publish their research get better teaching evaluations as the result of intellectual engagement. However, Bennis and O'Toole (2005) note that "Business school faculties simply must rediscover the practice of business. We cannot imagine a professor of surgery who has never seen a patient, or a piano teacher who doesn't play the instrument, and yet today's business schools are packed with intelligent, highly skilled faculty with little or no managerial experience. As a result, they can't identify the most important problems facing executives and don't know how to analyze the indirect and long-term implications of complex business decisions" (p. 103). Academics have come to value managerial experience but, normally, only once they get it.

Guides for more applicable learning demand fitting students, teaching that relationships rule, and using many new unorthodox methods to expand opportunities to require critical thinking and innovations. The general guidelines given here are good as a base for teaching strategy. As difficult as it would be to do, curriculums excellent in preparing MBAs for the world of commerce would be the opposite of uniformity and stability.

\section{Back to Strategy: Today as in Practice for Learning}

Strategy as dictated in classrooms is mostly theory, and its simplification mostly distorts reality. Strategies are about actions and moves - not plans and schemes (Powell, 2017). You can only tell what a strategy is after you see it in action: intentionality is extraordinarily important in strategy (Christensen, Allworth, \& Dillon, 2012). Few if any strategic plans are implemented exactly as formulated. Situations and the players change dramatically and quickly; the only sustainable advantage is adaptability (Spicer \& Hyatt, 2017).

Leaders, managers, strategist or innovators cannot be created in classrooms (Mintzberg, 1994, 2004, 2009). Yet, the skills, attitudes, and mindsets required for organizational success can be learned 
with engaged, focused intentionality. Improving strategic thought can be realized but not "caught" without experience. Teachers must try to help students (mentees) experience what they can in the classroom. Re-re-identify opportunities and mind all gaps. The axiom that "by thinking to learn, we learn to think" must be reinforced into the heads of teachers and leaders. Clarify your thinking before you start strategic thought. "Minding the gaps" is strategy: this implies you know 1) where you are and 2) where you need to be. We need to move from some doing strategy to all thinking strategically. Strategic thinking clarifies where we have been (perceptions), what is (reality), and what is yet to be (influencing this). Strategy is not what is planned or proclaimed, but what is demonstrated as resources and attention are applied (Service \& McEwen, 2015). Strategy works forward, for there is no hope for a better yesterday.

\section{Rapid Incremental Innovation - The Only Sustainable Strategy for Teaching, Learning and Doing}

Personal and organizational performance gains and survivability of teaching, researching, and doing are sustained by change. Every organization that competes needs a distinctive - a new strategy put into action again and again. The old solutions and teaching how to strategize have been neither effective nor efficient (Butler, 2007; Conard, 2012; Dorner, 1996; Gladwell, 2013; Asmus \& Grudem, 2013; Kaufman, 2010). Realizing economy-enhancing innovation requires that more people open their minds to think in a creatively competent way - but only after understanding what is truly clear thinking (Williams, 2010). The strategy for sustainable competitive advantage is rapid, incremental innovation. Use "dynamic capabilities as organizational routines and processes ... [through] combin[ing] resources and capabilities in new ways" (Barney \& Mackey, 2018, p. 12). Attempt to find newer different alternatives for addressing issues. Gaynor (2002) and Saba (2011) state that curiosity and choice were keys for people who succeed in leading in differing context: innovation from many angles. Choices have turning points, dangerous corners, tipping points or hinge factors that turn the tide for good or bad; every choice can be a determinate (Durschmied, 2016).

\section{Be Clear About What Strategy Is and Is Not}

Strategy's starts and ends with worldviews: where the world is and where it is going within your area of concern. A leader's strategy indicates what the leader's interpretation of the situation is (their reality) and the how, what, where, when, who, and why of accomplishing the leader's vision. Strategic thinking is a circular, never-ending process and does not follow the normal path of studying, planning, executing, evaluating, and adjusting (Service, 2006).

Barney $(1991,1995)$ calls repeatedly for products and services to be rare, of value, have no substitutes, and no imitations in order for the possibility of sustainable advantage. Add to Barney's extensive work Michael Porter's (all dates) call for products and services that are differentiated, low-cost, and/or focused. These seven points require continuous innovation, for one cannot remain ahead in any of these areas without change. Assertions about becoming and remaining innovative apply exponentially to those teaching strategy.

\section{Doing It? Pull It All Together}

Strategic mindset development and leadership for innovation are worldwide needs. Although the problems and solutions will likely differ, effective analysis and innovative strategies are universal. If you look you will see a form of strong support for the call for innovative thinking almost daily. For example, a recent article described a study of 500,000 employees and 800 companies that showed: "Companies that welcome ideas from all employees have better growth prospect than those with less-inclusive approaches ... Those employees were also $32 \%$ more likely to describe themselves as willing to put extra effort into work. . . I try to encourage our team to think outside [our industry] . . there are good ideas everywhere" (Chadha, 2018, p. B6).

Our proclamations go beyond the commercialistic deluge of media driven pop-culture to stress the fundamentals of the human influence labelled leadership. Effective innovative strategic leadership mindsets make or break strategy and encompass: 
1. truth/truthfulness and trust/trustworthiness;

2. personal and group development;

3. curious flexibility;

4. incremental and revolutionary knowledge expansion;

5. personal and organizational innovativeness;

6. cross-cultural appropriateness (even "within" for more and more organizations);

7. balanced creative and practical problem solving for fitting solutions;

8. accountability and collaboration;

9. leveraging and applying knowledge, skills, and abilities; and

10. seeking excellence through realization, reception, reflection, and reproduction.

\section{Prepare for What Will Be, Not What's Been}

All events are the result of many compounding factors interacting in complex and unpredictable ways. To shape a better future, our perspectives must capture much of the real complexity by encapsulating multiple perspectives. Develop a strategy for the might, can, want, ought, and need of your innovative contribution. Measure it, and it will improve. It is up to you and us, no one else, to guarantee our success. Always stay alert and avoid simply having slogans in place of a strategy. Exemplify the actions below to become and remain a more effective strategic leader/teacher.

1. Inspiring-actions and words: trust, trustworthiness, truth and truthfulness-core.

2. Wanting - desire, focused work: visioning and envisioning.

3. Understanding learning-roles-organizations (purpose, products), cultures, self, others, situations.

4. Selecting-focused attention on what matters: people, processes, situations and interactions.

5. Communicating- defining and sharing missions, visions and values.

6. Challenging- push yourself and others to reach forever higher levels of success.

7. Enabling-empower and leverage, for you cannot do it all.

8. Persuading- motivating self-others through communications, actions, rewards, penalties.

9. Modeling- behaving-as "the" example: manage image- 1 ounce of image $=1$ pound of performance.

10. Applying/doing- leveraging, building, developing, arranging-improving effectiveness.

You can't be if you don't do (Kaufman, 2010).

\section{CONCLUSIONS: WHAT WORKS?}

The only sustainable answers result from strategic leadership for and by rapid incremental innovation. Effective strategic leaders, teachers and doers masters application of these success factors:

1. Valuing trust and trustworthiness, truth and truthfulness over all other principles.

2. Clarifying organizational and self-direction. Imperatives: a) why you, b) innovativeness.

3. Obtaining and retaining knowledge, skills, abilities, attitudes, awareness.

4. Fitting into cultures before standing out in order to establish stronger and more effective cultures.

5. Recognizing talent-attract-keep it. Effectively use it to accomplish overriding org purposes.

6. Understanding organizations, organizing, management, empowerment, flatness, speed, learning.

7. Developing preferences for collaborations with smart partnerships-relationships rule.

8. Expanding and developing yourself and others as leaders of the future: mind those gaps.

9. Practicing mindsets that focus on organizational, societal, global and self-arenas.

10. Balancing work, spirit, learning, physical, emotional, and relational thoughts and actives.

Relearn, rethink and repurpose planning, strategizing and doing; but act. Management and leadership works through others' focus, effort, desire, realism, wisdom, and attention; have a strategy (Hunger \& Wheelen, 2011). Innovators are focused, but, “Don’t stay too focused” (Isaacson, 2014, p. 430). 


\section{Do It! Only by Thinking to Learn Do We Learn to Think: Learn and Teach This}

"Bad strategy abounds... [those] who can spot it stand a much better chance of creating good strategies" (Rumelt, 2011, p. 1). According to Rumelt, good strategies have diagnosis, guiding policy, and coherent action steps. Teach around this framework while not confusing knowing about something with knowing something. Do not stay in known ignorance or remain in the darkness of misplaced confidence; try something new. "People have to feel like it's OK to make mistakes and learn from them" (Furmans, 2018, p. B5).

The innovation directing and strategic leadership research is not complete and will never be (DuBrin, 2004; Service, Loudon, \& Kariuki, 2014); that must not stop the readers from using insights in this descriptive and prescriptive manuscript. This manuscript must cause us to think more, adapt and adjust more quickly as we strategically innovate the future. Always act, for no decision is a decision - and often the worst decision you can make in formulating and doing strategy. "[N]ot only can nothing become something, it is required to" (Krauss, 2012, p. 156). Of everything you contemplate think so what, so why, so how and end with so now, that is your immediate actions.

\section{REFERENCES}

Alsop, R. (2008). The trophy kids grow up: How the millennial generation is shaking up the workplace. New York, NY: Jossey-Bass.

Allison, J.A. (2015). The leadership crisis and the free market cure. New York, NY: McGraw Hill.

Asmus, B., \& Grudem, W. (2013). The Poverty of Nations: a sustainable solution. Wheaton, IL: Crossway.

Barney, J. (1991). Firm resources and sustained competitive advantage. Journal of Management, 17(1), 99-120.

Barney, J. (1995). Looking inside for competitive advantage. Academy of Management Executive, 9(4), 49-61.

Barney, J. \& Mackey, A. (2018). Monopoly profits, efficiency profits, and teaching strategic management. Academy of Management Learning \& Education, 17(3), 359-373.

Bedwell, W.L., Fiore, S.M., \& Salas E. (2014). Developing the future workforce: An approach for integrating interpersonal skills into the MBA classroom. Academy of Management Learning \& Education, 13(2), 171-186.

Bell, R.G., Filatotchev, I., Krause, R., \& Hitt, M.M. (2018). From the Guest Editors: Opportunities and challenges for advancing strategic management education. Academy of Management Learning \& Education.

Bennis, W.G., \& O'Toole, J. (2005). How business schools lost their way. Harvard Business Review, 83(5), 96-104.

Berg, J.M. (2016). Balancing on the creative highwire: Forecasting the success of novel ideas in organizations. Administrative Science Quarterly, 61(3) 433-468.

Bhardwaj, G., Crocker, A., Sims, J., \& Wang, R.D. (2018). Alleviating the plunging-in bias, elevating strategic problem solving. Academy of Management Learning and Education, 17(3), 279-301.

Blackard, K. \& Gibson, J.W. (2002). Capitalizing on conflict. Palo Alto, CA: Davies-Black.

Blair, T. (2010). A journey: My political life. New York, NY: Alfred A. Knopf.

Blinder, A.S. (2018, April 18). What they don't teach in Econ 101. The Wall Street Journal, p. A13.

Bogers, M., Chesbrough, H., \& Moedas, C. (2018). Open innovation: Research, practices, and polices. California Management Review, 60(2) 5-16.

Buckley, P.J. (2018). How theory can inform strategic management education and learning. Academy of Management Learning \& Education, 17(3), 339-358.

Buford, B. (2014). Drucker \& me: What a Texas entrepreneur learned from the father of modern management. Brentwood, TN: Worthy Publishing.

Bush, G.W. (2010). Decision Points. New York, NY: Crown. 
Calero, A.D., Barreyro, J.P., \& Injoque-Ricle, I. (2018). Emotional intelligence and self-perception in adolescents. Europe's Journal of Psychology, 14(3), 632-643. Retrieved October 2018, from http://doi.org/10.5964/ejop.v14i3.1506.

Calk, R., \& Patrick, A. (2017). Millennials through the looking glass: Workplace motivating factors. The Journal of Business Inquiry, 16(2), 131-139.

Carucci, R. (2018, October 29). When companies should invest in training their employees - and when they shouldn't. Harvard Business Review Digital Articles, p. 1-5.

Chadha, J. (2018, August 9). Innovation as a team wins. The Wall Street Journal, p. B6.

Charan, R. (2015). The attacker's advantage: Turning uncertainty into breakthrough opportunity. New York, NY: Public Affair.

Christensen, C.M., Allworth, J., \& Dillon, K. (2012). How will you measure your life? New York, NY: Harper Business.

Cohen, D. \& Prusak, L. (2001). In good company: how social capital makes organization work. Watertown, MA: Harvard Business School Press.

Corbin, J., \& Strauss, A. (2008). Basics of qualitative research: Techniques and procedures for developing grounded theory ( $3^{\text {rd }}$ ed.). Thousand Oaks, CA: Sage.

Data-driven decision-making: Business intelligence is at the heart of today's executive ed. (2017, June 15). Fortune: The Fortune 500 Double Issue, p. 17.

Davenport, T.H., \& Beck, J.C. (2001). The attention economy: Understanding the new currency of business. Watertown, MA: Harvard Business School Press.

Dobelli, R. (2013). The Art of Thinking Clearly. New York, NY: HarperCollins.

Dorner, D. (1996 translation). The logic of failure: Why things go wrong and what we can do to make them right. New York, NY: Henry Holt and Company.

Drucker, P. (2013). HBR's 10 must reads on innovation. Boston, MA: Harvard Business Review Press.

Duckworth, A. (2016). GRIT: The power of passion and perseverance. New York, NY: Simon \& Schuster.

Durschmied, E. (2016). How chance and stupidity have changed history: The hinge factor. New York, NY: Arcade.

Felsenthal, E., \& Pine, D.W. (2018). The science of creativity. New York, NY: Time Inc. Books.

Fischer, T., Dietz, J., \& Antonakis, J. (2017). Leadership process models: a review and synthesis. Journal of Management, 43(6), 1727-1753.

Friedman, H.H. (2018). Is higher education making students dumb and dumber? Retrieved from https://www.researchgate.net/profile/Hershey_Friedman/publication/318710780_Is_Higher_Educ ation_Making_Students_Dumb_and_Dumber/links/5b67827da6fdcc18834808b1/Is-HigherEducation-Making-Students-Dumb-and-Dumber.pdf

Friedman, T.L. (2005). The world is flat: A brief history of the twenty-first century. New York, NY: Farrar, Straus, and Giroux.

Friedman, T.L., \& Mandelbaum, M. (2011). That used to be us. How American fell behind in the world it invented and how we can come back. New York, NY: Farrar, Straus and Giroux.

Furmans, V. (2018, July 26). OBM's go-to disrupter runs on change. The Wall Street Journal, p. B5.

Gaynor, G.H. (2002). Innovation by Design. New York, NY: AMACOM Publishing.

George, B., \& Sims, P. (2007). True North: Discover Your Authentic Leadership. San Francisco, CA: John Wiley \& Sons, Inc.

Gerstner, L.V., Jr. (2002). Who says elephants can't dance. New York, NY: HarperBusiness.

Gilley, A., McMillan, H.S., \& Gilley, J.W. (2009). Organizational change and characteristics of leadership effectiveness. Journal of Leadership \& Organizational Studies, 16(1), 38-47.

Gladwell, M. (2005). Blink: The power of thinking without thinking. New York, NY: Little, Brown and Company.

Gladwell, M. (2008). Outliers: The story of success. New York, NY: Little, Brown and Company.

Gladwell, M. (2013) David and Goliath: Underdogs, misfits, and the art of battling giants. New York, NY: Little, Brown and Company. 
Grant, R.M. (1996). Toward a knowledge-based theory of the firm. Strategic Management Journal, 17, 109-122.

Grant, R.M., \& Baden-Fuller, C. (2018). How to develop strategic management competency:

Reconsidering the learning goals and knowledge requirements of the core strategy course. Academy of Management Learning \& Education, 17(3), 322-338.

Haidt, J. (2012). The righteous mind: Why good people are divided by politics and religion. New York, NY: Vintage Books.

Harari, O. (2005). The Powell principles: 24 lessons from Colin Powell, battle-proven leader. New York, NY: McGraw-Hill.

Heames, J.T., \& Service, R.W. (2004). Dichotomies in teaching, application and ethics. Journal of Education for Business, 79(2), 18-22.

House, J. (n.d.) Winston Churchill: His wit and wisdom. London: Hyperion Books.

Hunger, J.D., \& Wheelen, T.L. (2011). Essentials of Strategic Management (5th ed.). Upper Saddle River, NJ: Prentice Hall.

Isaacson, W. (2007). Einstein: His Life and Universe. New York, NY: Simon and Schuster.

Isaacson, W. (2014). The innovators: How a group of hackers, geniuses, and geeks created the digital revolution. New York, NY: Simon and Schuster.

Kaufman, J. (2010). The personal MBA: Master the art of business. New York, NY: Portfolio Penguin.

Klein, M., \& Napier, R. (2003). The courage to act. Palo Alto, CA: Davies-Black.

Krauss, L.M. (2012). A universe from nothing: Why there is something rather than nothing. London: ATRIA.

Landsburg, S.E. (1993). The armchair economist, economics and everyday life. New York, NY: The Free Press.

Levitt, S.D., \& Dubner, S.J. (2014). Think like a freak: How to think smarter about almost everything. New York, NY: Penguin Books.

Manzoni, J.F., \& Barsoux, J.L. (2002). The set-up-to-fail syndrome: How good managers cause great people to fail. Boston, MA: Harvard Business School Press.

McChrystal, S., Eggers, J., \& Mangone, J. (2018). Leaders: Myth and reality. New York, NY: Penguin.

Miller, C.B. (2018). The character gap: How good are we? Oxford: Oxford Press.

Mintzberg, H. (1994). The rise and fall of strategic planning. Toronto: The Free Press.

Mintzberg, H. (2004). Managers not MBAs: A hard look at the soft practice of managing and management development. San Francisco, CA: BK Publishers, Inc.

Mintzberg, H. (2009). Managing. San Francisco, CA: Berrett-Koehler.

Mintzberg, H., Ahlstrand, B., \& Lample, J. (2005). Strategy bites back. Upper Saddle River, NJ: Pearson Prentice Hall.

Molenberghs, P., Prochilo, G., \& Steffens, N.K. (2015). The neuroscience of inspirational leadership: The importance of collective-oriented language and shared group membership. Journal of Management, 43(7). 2168-2194.

Moschieri, C., \& Santalo, J. (2018). The impact of research performance on students' evaluations for strategy professors in business schools. Academy of Management Learning \& Education, 17(3), 302-321.

Nielsen, D., \& Sirkel, E. (2017). Be an inspirational leader: Engage inspire empower. U.S.: Dan Nielsen Company.

Obama, B. (2004). Dreams from my father: A story of race and inheritance. New York, NY: Three Rivers Press.

Obama, B. (2006). The audacity of hope. New York, NY: Crown Publishers.

O'Loughlin, J. (2003). The real Warren Buffet. London: Nicholas Brealey Publishing.

Olsen, G.D. (2012). The 5 laws of innovation success: Generating critical momentum for products, services and ideas. Phoenix, AZ: Novetics Press.

Peng, M.W., Nguyen, H.W., Wang, J.C., Hasenbuttl, M., \& Shay, J. (2018). Bringing institutions into strategic teaching. Academy of Management Learning \& Education, 17(3), 259-278. 
Perlow, L.A. (2003). When you say yes but mean no. New York, NY: Crown.

Peters, T.J. (1987). Facing up to the need for a management revolution. California Management Review, Winter, 7-37.

Peters, T.J. (2003). Re-Imagine! New York, NY: Dorling Kindersley.

Porter, M.E. (1980). Competitive strategy. New York, NY: Collier Macmillan.

Porter, M.E. (1985). Competitive advantage. New York, NY: Macmillan.

Porter, M.E. (1990). The competitive advantage of nations. New York, NY: Macmillan.

Porter, M.E., Lorsch, J.W., \& Norhria, N. (2004). Seven surprises for new CEOs. Harvard Business Review, October, 62-72.

Powell, T.C. (2017). Strategy as diligence: Putting behavioral strategy into practice. California Management Review, 59(3), 162-190.

Priem, R.L. (2018). Toward becoming a complete teacher of strategic management. Academy of Management Learning \& Education, 17(3), 374-388.

Rumsfeld, D. (2013). Rumsfeld's rules. New York, NY: Broadside Books.

Rumelt, R. (2011). The perils of bad strategy. McKinsey Quarterly, 1(3), 1-10.

Saba, A.S. (2011). Roll the dice: Are we gambling with global employee selection? A reassessment of competitive alternatives. Proceedings from The International Academy of Business and Public Administration Disciplines. Memphis, TN, p. 388.

Schawbel, D. (2013). Promote yourself: New rules for career success. New York, NY: St. Martin's Griffin.

Service, R.W. (2006). The development of strategic intelligence: A managerial perspective. International Journal of Management, 23(1), 61-77.

Service, R.W. \& Loudon, D.L. (2015). Critical issues: Academia trumped by truth or consequences. European Open Education Research Journal, September, 1-22.

Service, R.W., Loudon, D.L., \& Kariuki, K. (2014). Cross-cultural leadership: Recommendations for Kenya. Journal of Social Economics Research, 1(4), 40-71.

Service, R.W., \& McEwen, J.K. (2015). Innovation creates the future when it exemplifies clear strategic thinking over reacting to presenting complaints. Strategic Management Quarterly, March, 1-48.

Service, R.W., \& Reburn, J.P. (2016). Skills that matter and will last a lifetime. International Journal of Education and Practice, 4(5), 183-206.

Service, R.W., Reburn, J.P., \& Windham, J.R. (2017). The character of leadership: Is leadership. European Journal of Management, 17(2), 49-72.

Shapiro, D.L., \& Kirkman, B. (2018). It's time to make business school research more relevant. Harvard Business Review, July. Retrieved from https://hbr.org/2018/07/its-time-to-make-business-schoolresearch-more-relevant.

Sinek, S. (2011). Start with why: How great leaders inspire everyone to take action. New York, NY: Portfolio.

Sinek, S. (2014). Leaders eat last: Why some teams pull together and others don't. New York, NY: Penguin.

Stern, C.W., \& Deimler, M.S. (2006). The Boston Consulting Group on strategy. Hoboken, NJ: John Wily \& Sons.

Teece, D., \& Pisano, G. (1994). The dynamic capabilities of firms: An introduction. Industrial and Corporate Change, 3(1), 537-556.

Tjan, A. (2017). Good people: The only leadership decision that really matters. New York, NY: Portfolio.

Welch, J. (2001) Jack: Straight from the gut. New York, NY: Warner Books.

Wood, P., \& Randall, D. (2018, April 16). How bad is the government's science? The Wall Street Journal, p. A17. 